ノ挗入及ビ操縱困唯:ニシテ且ツ鏡像轉倒セルタ メ部位 7 定メ難 ク殊 $=$ 虽吐 7 催ス場合等不適賞 ニシテ腹位ニ於テハ之等ノ不便ナク最モ理想的 位置タルラ疑ハズ。但シ呼吸困難，高度/心悸 充進ノ場合及ビ婎娠末期ニ八禁忌トセリ。佾木

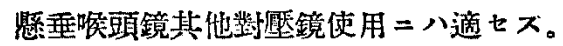

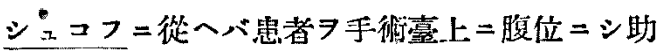
手八患者，左 $=$ 立右手 $=$ 患者，前額部 上セシムル樣二支持ス。患省八右手 =テ舌 7 持 チ. 左手八驅幹二沿ハシム. 術者八廻轉椅子= 腰习掛ク。

余八检查中必要二隹ジX線透视 7 行ヒ得ル樣透

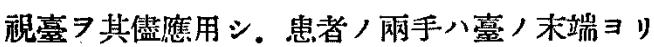
自然ニ垂レシメ且ツ術者八呬轉椅子ヨ用ヒズエ ーナ. $\boldsymbol{i}_{2}$ シヘン爾大學二設備セルモノ 7 落考 トシテ造リタル深サ $5.5 \mathrm{~cm}$, 直徑 $6 \mathrm{~cm} /$ 穴 (Senkgrube）內二立チテ極メテ容易二心地良ク直 涬鏡检查 7 䆩施シ居レルラ以テ茲二推獎スル所 以ナリ:

\section{2. 耵棕ノ性狀卜外聽道分泌腺二}

關ス儿研究補遺 平山正健(繁 北)

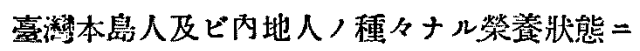
於分疾患者尼體 41 笛中本島人男 16 名. 女 7 名. 内地人男 13 名. 女 5 名 $=$ 于年夦的 $=八$ 生 後 70 日ョリ 70 歲=至ルモ，、雨側外㽬道及ビ

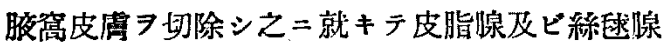
ノ形狀，多察．機能狀態及ビ含有脂肪物貿 /檢

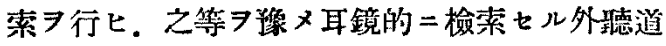

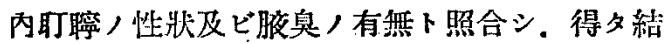

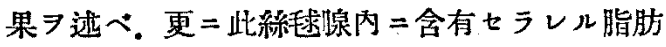
物質二就キテ檢討ラ行ハントス。

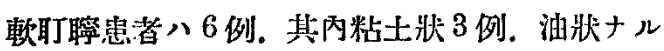

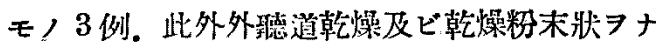

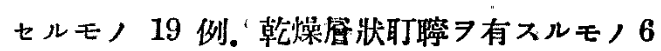

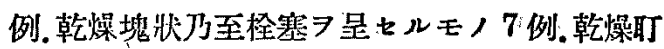
貯ナリシモ中耳炎二程恝シテルモノ3 例ナリ。 軟耵瞌患者中 3 名八强キ胶鬼 7 有シ 3 名八其程 度弱シ。軟耵瑏者中 2 例八外獣道壁二甚ダ多ク 分布發充七几皮脂腺卜脊，高1大ナル圆柱形細

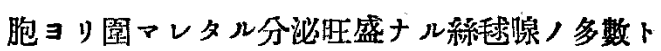
ヨリ成り. 類脂肪顆柆, 合量多シ。腋臭强 $\neq 2$

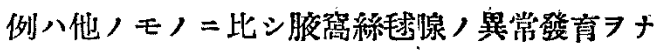
シ. 細胞八特=圆柱形. 大ナルモ類脂肪顆粒,

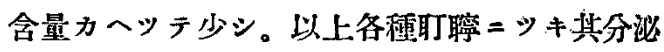
腺及ビ腺內要素，平均價 7 標示シ．之ア綡合え

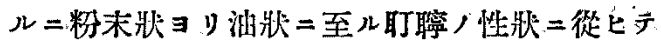

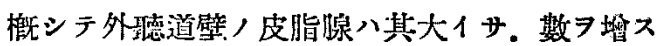
千含有脂肪物質 $=$ 變化ナク，綵逐腺认次第 $=$ 骰 子形乃至扁平ヨり其細胞ハ大且ッ圆柱形卜ナリ 機能，六進 7 示ス。又絲述腺內類脂肪顆粒(厂 ルブラウ」陽性.「シャチオ」陽性顆粒) 及ビ色 装顆粒フ增加スル傾向フ見ル。但シ「ズダン」III

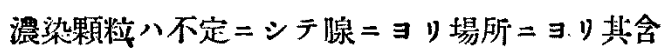

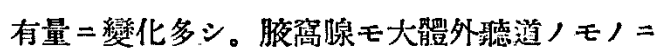
準ジテ變動フ示スモ必ズシモ作行セズ。

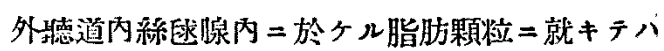
2 群, 脂肪 nukulär 或八屜平ナルモグ二於テハ核/网端 二接シテ集マレル脂肪細顆粒ニシテ此モノハ多 少ニ拘ラズ常ニ殆ンド總テ，該絲我腺細胞中二 含有七ラレ、特二圓柱形大ナルモ/二多シ。而 シテ色素顆粒卜其排列相似タリ。多クハ色素顆 粒二附着スル如シ。他八比較的粗大顆粒 裳 $=$ 平等 $=$ 念有七ラレズ. 或腺 $゙$. 又或細胞 ’ 特ニ多シ。或例二テハ全然有セザルモノケ リ。前者八種々ナル脂肪溶鈹 (Äther, Alkohol, 
Aceton, Xylol, Chloroform) 等二難溶ナリ。 之等ニ行ヒタル種タナル脂肪染色及ビ物理學的 性狀 卜 Aschoff-Kawamura，脂肪群屬反應 7 照合シ此前者脂肪顆粒立八皮脂骔. 軟骨內 ノ夫レ ト異ナリ Berberich /所謂 Cephalin 乃至 Cholesterin +Cephalin $=$ 相當シ. 色素ト共 $=$

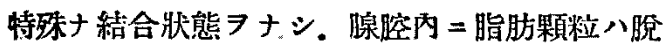
落細胞以外二認メザル所引リ該腺細胞獨特, 作 用二關與スルモノナラント考へラル。後者八通 常/皮脂腺內ノ脂肪顆粒卜同ジ。此モノガ腺細 胞二固有ノモノナルヤ脂肪變性二傾キタ，ル二次 的所迹ナルヤ八分明七ズ。腋简絲医腺内 =モ二 重屈折脂肪顆粒及ビ, epinukülar ，脂肪細顆粒 ヨ有スルモノアルモ不定且ツ不分明ナリ。二重 屈折脂肪顆粒八細胞，圆柱形. 大ナルモノョリ 侮子形ノモノニ多ク之ヨ認メタリ。而シテ其存 在モ不定ナリキ。

\section{3. 酸味果實並二醋酸/中耳炎治痖二 及ボス影響二就テ}

中岛彰(飠孯)

酸味高度，果實攝取並二酸味食力゙。中耳炎治

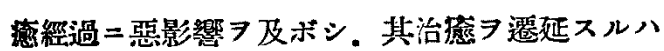
既二山崎(春)氏 $=ヨ$ リ臨彇報告シナサレシ所ナ ルモ。余八酸味强度ナル柑橘類 (蜜柑。橙) 並 $=5 \%$ 人醋酸 7 海猽=投與シ，是等/中耳炎症 二及ボス影響二關スル實驗的研究习行ヘリ．試 獸ハ比較的幼若ナルモノフ選ビ. 體重 $1 \mathrm{~kg}=$ 付 + $5 \mathrm{~g}$ ，割合 $=$ 前記，果汁又八醌酸 7 雪花荣= 混合シテ與一，正常食毁投與群（雪花荣7主食 トシ. 1 週間 $=2$ 回適當量，青草习與フ）ト比 较對照七り。

組織學的所昌

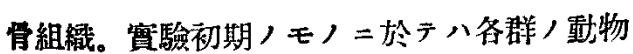

間二、著シキ差異フ認メズ，郎チ，骨皮質人

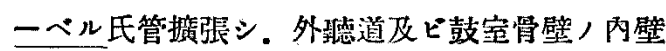
ニ八所タ＝破骨細胞附着浸強シ．骨壁線ガ鋸苳 狀凹凸ヨ示スモ，多シ。各辞二於ヶル中耳骨 壁ノ厚サヨ比較セント欲シ. 各動物ノ中耳腔底 部ノ一定部位ヨ選ビ. 其骨壁ノ厚サヨ測定セシ =. 菲照群 : 相蕾群 : 醋酸群二11:10:11 比率 ニシテ.著シキ差異热シ。(厚サ)實數值八是等 ノ數字=20 ，骨新生作用旺盛ニシテ，其丙外骨壁=多數ノ 新生骨梁附着シ且ツ該骨梁表曆ニ八盵厚七ル造 骨細胞雊列スルラ認ム。斯カル造骨現象八菌注 入後 1 ケ月内外 7 經タルモノ二於テ最モ顯著二 シテ.該新生骨梁八篩狀 $コ$ 是シ。固有骨壁八其中 二埋没セルガ如キ狀 後 4 週間 7 經タル各群動物二於ケふ前述，比率 ア見ル =. 40:50:55 ニシテ柑橘群並=醋酸群 八對照群二比シ高度. 且ツ軳粗ナル骨新生 7 營 ムヨ見ル。然レ共. 望驗後日 7 經タルモノト踓 モ.上鼓室.副室等二膿汁潜溜七ルモノニアリテ 八. 該骨壁內面=多數ノ破骨細胞附着シ，骨新 生，傾向㱠ンド然キモ，アリ。斯カ儿症例八長 期間投與七几枯橘群亚=醋酸群二比較的多ク認 ム、骨性迷路=於テ八，海猽，螖牛殼八中耳腔 内二露出七ルラ以テ，該骨壁八炎症性浸潤习蒙

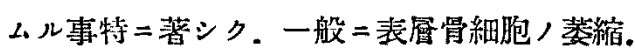
骨細胞核, 染色不鮮明等 7 招柬シ。骨壁/菲薄 トナレルモノ多ク。外骨壁ノ肥厚八。中耳炎惹 起後1 万月ヨ經タルモノ二輕度=認ムルノミナ リ。骨壁ノ破㙥穿孔七ルモノョ見ル二。對照群 $=1$ 例. 相露群 $=4$ 例. 醋酸群 $=5$ 例 7 認山。 軟部組織。各群甜;物，大多數例二於テ，多量

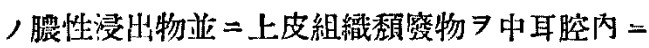

